UDC 669.14.018.821-138

\title{
外国製噴霧ステンレス鋼粉の品質比較試験
}

\author{
加 藤 哲 男*, 草 加 勝 司 ${ }^{* *}$
}

\section{Comparative Study of Some Stainless Steel Powders}

\section{Tetsuo Katô and Katsushi Kusaka}

\section{Synopsis}

Some properties were studied to be compared about stainless steel powders of $304 \mathrm{~L}, 316 \mathrm{~L}$ and $410 \mathrm{~L}$ which were imported and marketed.

Through a synthetic investigation on qualities from metallurgical point of view the results were confirmed as follows :

(1) All atomized stainless steel powders are comparatively good in compactibility, because of (round) irregular shape, and are lower in compressibility than atomized iron powder and low alloy steel powder.

(2) However, larger shrinkage in sintering gives fairly higher sintered density. Especially, as the result of larger densification of 410L, its mechanical properties are comparatively near to those of molten materials.

(3) For the corrosion resistance, sintered stainless steels are much inferior to those of molten materials respectively.

(4) The micron-size stainless steel powders manufactured by the coldstream method will be used as the means of making higher density-parts by mixing only under proper processes.

\section{1. 緒}

\section{霄}

最近の粉末や金工業は急速に発展し，鉄粉や銅粉に 限らす低合金銅、ステンレス銅などの合金銓粉の分野 へす進出しつつあり, その方面の研究や工業化も盛儿 に行なわれている。とくに粉末製造法の一つとして 1940年代に始むるいわゆる溶湯噴弱法はこれらプレア ロイ粉末の量産化'支可能にし，焼結鍛造やアイソス タチック・プレスなど焼結材の高密度, 高強度化への 新しい技術とともに大きな需要面を切り開きつつあ る。

この情勢に対し，特殊鎉メ一カの立場からこれら粉 末や金用原料粉としてのプレフロイ粉末の諸性質を知

昭和 49 年 2 月 17 日受付

*大同製鋼研究開発本部中央研究所, 工博

**大同製鋼研究開発本部中央研究所
り，得られる焼結材の性能を通常の溶製材との対比に おいて，は握して打く必要があると考える。 この目的で国内外の市販鉄粉，低合金鋼粉などの特 性試験を続け，その性能をは握することにしてきた が，とくにその5ち金属学的にも関心のある噴霧ステ ンレス銅粉を対象にし，世界的な粉末製造メ一力 4 社 の市販 (噴霞)ステンレス鋼粉を入手し，粉末の性状， プレス一焼結性および焼結材の機械的性質，耐食性な どの特性試験を行ない，相互に品質を比較した。ま た，同時にその諸性質を鉄粉，低合金銅粉および溶製 材についての資料を加え検討したので，その結果をま とめて報告する。

\section{2. 試料および試検方法}

水噴篛ステンレス鋼粉として，Glidden（米国）の $304 \mathrm{~L} ， 316 \mathrm{~L}$ および $410 \mathrm{~L}$ と Höganäs（スエーデ 
Table 1. Chemical analysis.

\begin{tabular}{|c|c|c|c|c|c|c|c|c|c|c|c|c|c|c|}
\hline \multirow{2}{*}{$\begin{array}{c}\text { A I S I } \\
\text { No. }\end{array}$} & \multirow{2}{*}{$\begin{array}{l}\text { Powder } \\
\text { makers }\end{array}$} & \multicolumn{12}{|c|}{ Chemical compositions (\%) } & \multirow{2}{*}{$\begin{array}{c}\text { H.loss } \\
(\%)\end{array}$} \\
\hline & & $\mathrm{C}$ & $\mathrm{Si}$ & $\mathrm{Mn}$ & $\mathrm{P}$ & s & $\mathrm{Cu}$ & $\mathrm{Ni}$ & $\mathrm{C}_{\mathrm{r}}$ & Mo & $\mathrm{S} \cdot \mathrm{Al}$ & $\mathrm{I} \cdot \mathrm{Al}$ & $\mathrm{N}$ & \\
\hline \multirow{5}{*}{$304 \mathrm{~L}$} & Glidden & .023 & .72 & .15 & .011 & .017 & .28 & 10.78 & 19.17 & & $\leq .002$ & $\leq .002$ & .053 & .26 \\
\hline & Höganäs & .014 & .77 & .06 & .009 & .022 & $\leq .02$ & 10.02 & 19.03 & & . & 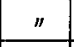 & .015 & .31 \\
\hline & M. Int. & .022 & $"$ & .12 & .013 & .012 & .05 & 10.13 & 18.03 & & 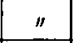 & $"$ & .028 & .20 \\
\hline & CS-powder & .044 & .26 & .16 & .011 & .011 & .04 & 9.33 & 18.81 & & .080 & " & .045 & - \\
\hline & B. S. A. & .032 & .62 & .17 & .012 & .013 & .03 & 10.90 & 18.55 & & $\leq .002$ & $"$ & .040 & .23 \\
\hline \multirow{5}{*}{$316 \mathrm{~L}$} & Glidden & .019 & .88 & .41 & .011 & .016 & .08 & 12.30 & 16.94 & 2.20 & $"$ & $"$ & .046 & .25 \\
\hline & Höganăs & .026 & .90 & .24 & .013 & .015 & $"$ & 12.81 & 17.37 & 2.40 & $"$ & $"$ & .047 & .40 \\
\hline & M. Int & .037 & .65 & .13 & .016 & .014 & .06 & 12.52 & 16.19 & 2.52 & $"$ & $"$ & .043 & .33 \\
\hline & CS-powder & .051 & 1.12 & .14 & .009 & .012 & .07 & 10.46 & 17.04 & 2.24 & $\prime \prime$ & $"$ & .056 & - \\
\hline & B. S. A. & .028 & .65 & .16 & .017 & .016 & .03 & 12.42 & 16.83 & 2.34 & $"$ & $"$ & .033 & .23 \\
\hline $410 \mathrm{~L}$ & Glidden & .021 & .82 & .05 & .010 & .021 & .09 & .20 & 12.23 & & $"$ & $"$ & .065 & .41 \\
\hline $\begin{array}{c}300 \mathrm{M} \\
\text { (Iron } \\
\text { powder) }\end{array}$ & A. O. S mith & .001 & $\leq .01$ & .19 & .007 & .012 & .04 & .03 & $\leq .02$ & $\leq .03$ & $"$ & $"$ & .005 & $.09^{3}$ \\
\hline 4600 & Glidden & .015 & .13 & .29 & .009 & .032 & .09 & 2.13 & .11 & .30 & $"$ & $"$ & & $.07^{\circ}$ \\
\hline
\end{tabular}

$* 1,200^{\circ} \mathrm{C} \times 1 \mathrm{hr} \quad\left(1,050^{\circ} \mathrm{C} \times 1 \mathrm{hr}\right.$ where $\left.300 \mathrm{M} \# \& 4600\right)$

ン), Metallurgical International (米国), B S

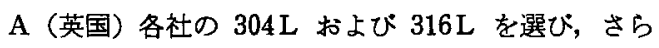
にM. Intern. (以後略) で開発した Cold-stream 法（水噴霧後さらに低温でインバクト粉伜）によるサ ブ・ミクロンオーダのステンレス鎆粉304Lおよび316 Lの二つをあわせ，計11種類を試験の对象とした。こ れら輸入市販のステンレス鋼粉の化学成分と水素ガス 中の $1,200^{\circ} \mathrm{C}$ での H-loss (JIS M3-63) の值をまと

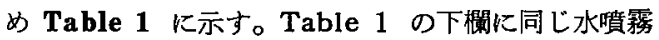
法による A. O. Smith（米国）の 300M 鉄粉と上記 Gliddenの 4600 粉の二つを加えたが，これらを以後 の比較試料にすることとした。

各粉末の性状は外観，断面およびミク口組織，かたさ の饬か内質的な特性についてはX線回断，磁気分析な どによる調查も合わせて行なった。せた，ロータップ 振と5機により粒度分布を求め, 一部粒度のものに対 し形状因子として最も簡単な Elongation factor ${ }^{2}$ )

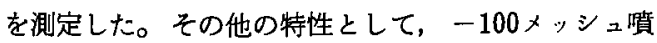
霛粉について見掛け密度（JIS Z 2504）および流動度 （JIS Z 2502）を湘定した。また，噴䨓粉のほか，そ れと Cold-stream 粉 (以後C S粉と略す) の混合系 として，後者を $100 \%$ まで均一に混入したるのについ ても適宜試験を実施した。

つぎに，各粉末を直径 $10 \mathrm{~mm}$ の円柱状ダィスでフロ ーティング・ダイ方式により最高 $12 \mathrm{t} / \mathrm{cm}^{2}$ をで加圧 $(50 \mathrm{t}$ アムスラー試験機を使用，ステフリン酸覀鉛 1 \%混入）し，スブリング、バックによる誤差を防ぐた
め個々の圧粉体についてグリーン密度（比）を求め, また圧縮率を計算した。この压縮性に続き，成形性と してはグリーン抗折力とラトラー值を取上げ，てれぞ れASTM B312-58T およびJSPM 4-69 に準じ，上 記と同じブレス成形操作（ステフリン酸业鈴0.75また は $1 \%$ 混入）により压粉体を作り，試験した。

焼結性については上記王縮性の試験で得られた試料 を $500^{\circ} \mathrm{C}$ て脱万5後 $1,180^{\circ} \mathrm{C}(\times 40 \mathrm{~min})$ で真空焼結 乙，対応する烧結体の寸法変化率や密度（比）を求 ぬ，また体積变化率，ち密化保数も適宜算出した。こ れとは別に，焼結温度に対してはASTM (JSPM) 規格によるダイス（底面 $1 \mathrm{~cm}^{2}:$ ステフリン酸垔鉛 $0.75 \%$ 湜入）で得られた王粉体のほか，前記グリーン 抗析力試験用と同じたんざく状の試料を加え，900〜 $1,350^{\circ} \mathrm{C}(\times 1 \mathrm{hr})$ の範囲で真空焼結 $L$, 前者から寸 法変化率や密度（比）を求め, 後者では片持ばりの曲 げ試験8をを行なった。試験後，試料のポフー・モホロ ジーやミクロ組織を調べ，かたさ，結晶粒度の測定む つけ加えた。また，燒結㭙の過渡現象についてはデラ ト・メータ（高周波加熱）を使い，小試片て温度に対 する膨脹一収縮を連続的に観察した。

焼結体の機械的性質として弓張り試験と衙辀試験の 二つを実施した。それぞれの形状の試片（後者は JIS Z 2202-3 号：ノッチなし）を100 $\mathrm{t}$ 万能試験機により $7 \mathrm{t} / \mathrm{cm}^{2}$ で加圧（ステアリン酸亜鈆0.75\%混入）し， 得られた圧粉体を $500^{\circ} \mathrm{C}$ で脱万弓後 $1,180^{\circ} \mathrm{C}(\times 2$ hr）で真空焼結し，そのまま試験に供した。後者に 
ついてはかたさや走查電子顕微鏡による破断面の観察 などを行なった。また，耐食性については同じよらな 細長い試料をプレス压 2〜10 t $/ \mathrm{cm}^{2}$ の笧囲（ステフ リン酸亚鈆 $0.5 \%$ 混入）で作り， $48 \mathrm{hr}$ の塩水噴霧試 験（JIS Z 2371 : 鋭敏化処理なし）を行ない, ミクロ 組織を観察した活か，一部は見掛け上の表面積から比 夜量を決定し，65\%沸腾硝酸と $5 \%$ 沸騰研酸中の䋀食 隇量を測定した。通常の溶製材に比べ浸食か大きいの で，試験時間はそれぞれ 6 および $1 \mathrm{hr}$ にとどめた。

\section{3. 試瑍結果と考察}

\section{1 粉末の性状}

Table 1 の化学成分からいずれの噴霧ステンレス

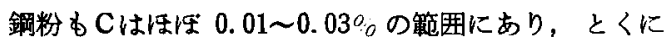
Glidden 粉は 3 鋼種とも比校的低い。これに対し両 C S粉はともにこれらより高くなっているか，それは 製造プロス上の原因によるものではないかと考觉ら れる。また，噴䨏粉において Si にあり，一方，Mnはかなり低く押光られており（Glidden $316 \mathrm{~L}$ 粉は Mn 約 0.4\%でミル・シートの值よ り高い), 両者の成分は通常の溶製材と比べ逆の傾向 になっている。

一般に，溶湯を水噴霧するとその表面に酸化膜が生 成するか，とくにステンレス鋼粉のような場合には $\mathrm{Cr}_{2} \mathrm{O}_{8}$ などの摆元しにくくかたい酸化物ができると， 後の諸プロセス上好ましくない。このため $\mathrm{Si}$ を0.5\% 以上とし，製造時の高温酸化を一時的に防ぎ金属光沢 を持たせているもの4で，これは同時に粒子を不規則 形状化し，見掛忛密度を低くする傾向到がある。逆 に，Mnは酸化物を作りやすく，粒子を球状化するの で好ましくない上5である。主成分である $\mathrm{Ni} ， \mathrm{Cr}$ 打 よびMoは溶製材の該当 AISI 規格の範囲内に入って いるが，Ni はやや低めをねらっているよ5である。 その他の不純物レベルは同じく水噴野し, 遷元処理さ れた $300 \mathrm{M} ， 4600$ と活汪同じ程度に低い。粒表面の酸 化物の目安となるH-loss は，喷籍ステンレス鋼粉で はいずれる $0.2 〜 0.4 \% て ゙ あ り ， 300 \mathrm{M} ， 4600$ より数倍 高いことを知る。 $0{ }^{\circ} \mathrm{C}$ 以下の低温ぜ、性を利用して粉 化処理 $\left.{ }^{6}\right)$ された両 C S粉については0.4\%程度 ( $\mathrm{Fe}-\mathrm{O}$ 分析で 0.5\%以上）で，必ずしす〔0]污染は少なく ないようである。

代表的な粉末の外観およびミク口組織の例ををとめ て Photo. 1 扰よび 2 に示す。水噴霧粉はいずれも 特有の Round irregular spheroid を呈している, オーステナイト系については組織的な $\delta$ 相はあまり䫓 著でない。噴蓩後， $410 \mathrm{~L}$ は軟化䡒なましされるとい
われるがその形状への影響はとくに見られず，明りよ らなフェライト結晶粒界が均一に㧍かっている。内部 の空孔は還元鉄粉などに比べて少ないが，さらに個々 の粒子を走查電子顕微鏡で観察するとその表面卜ポグ ラフィーは変化に富んでおり，粉末凝固時のガス放出 によると思われる小さな空孔中結晶粒界らしい周期的 な起伏などが見受けられた。これに対し両CS粉はと もに微細であり，走查電子顕微镜で 2,000 倍近くまで 拡大すると Photo. 2のよ5に5ろこ状で, Angular な端面などに強くぜ、性破壊を受けた跡がはっきり認 められる。

通常オーステナイト系と称世られる成分の材料で む, このステンレス鋼粉のよ5に Si が $1 \%$ 近く入り Ni-レベルが低めであると，当然噴楞時の急冷により (Coring effect ${ }^{7)}$ ) 高温 $\delta$ 相か残るはずであるが, X線回折や磁気分析の結果では数\%フェライト相が㒛 められた。(偏析のためか前者の值の方が高めに出 た)。なお，この相は約 $800^{\circ} \mathrm{C}$ での焼なましで任とん ぞ分解され $r$ 単相に戻る。しかしこの程度のフェ ライト混相は, 後のプレス瓦縮性にほとんど差を生じ ないことを確認しているらう。

つぎに，各粉末のマイクロビッカースかたさを測定 しまた噴籍ステンレス鋼粉については Elongation factor（Ef）を測定した結果を Table 2 の左側に 並べて示す。かたさはオーステナイト系のステンレス 鍋粉ではいずれも $\mathrm{HmV}:$ 130〜160 の籁囲にあり, 還元処理された 4600 と大差ない。これに対し $410 \mathrm{~L}$ は軟化焼なむししてあるにもかかわらず 170 近くあり (噴霧状態で 200 以上 ${ }^{8)}$ ), 多少之も圧縮性に影響す るのではないかと思われる。一方，CS粉は微細でか たさ測定はもり（大略 350 以上）であったが，X線回 折により調べたところ，刘応する M. Intern. の姺算 ステンレス鋼粉に比べ，相当量の $\alpha$ 相が生成しており とくに $304 \mathrm{~L} て ゙ は 60 \%$ 近いこと，そのブロファィルは 大きくBroadening し(半佂幅で約 3 倍), 粒度の差 からくる影響を考虑しても相当ひずんでいることがわ かった。これは生成時の激しい加工硬化によりマルテ ン化したものと考えられるが，一般にこの種ステンレ 又鋼の冷間強加工時に生成する中間相 $(\varepsilon)$ の存在は はっきりしなかった。Ef はいずれる 1.5 前後 (平均 的なー200/+325 メッシュ粉の值を記した）にあって

Höganäs の両鋼粉ではともに比較的細長いが，貲 笼メカニズム日) 上から予想されるとおり，いずれも粒 度の小さい側で球状化しているのか認められた。 

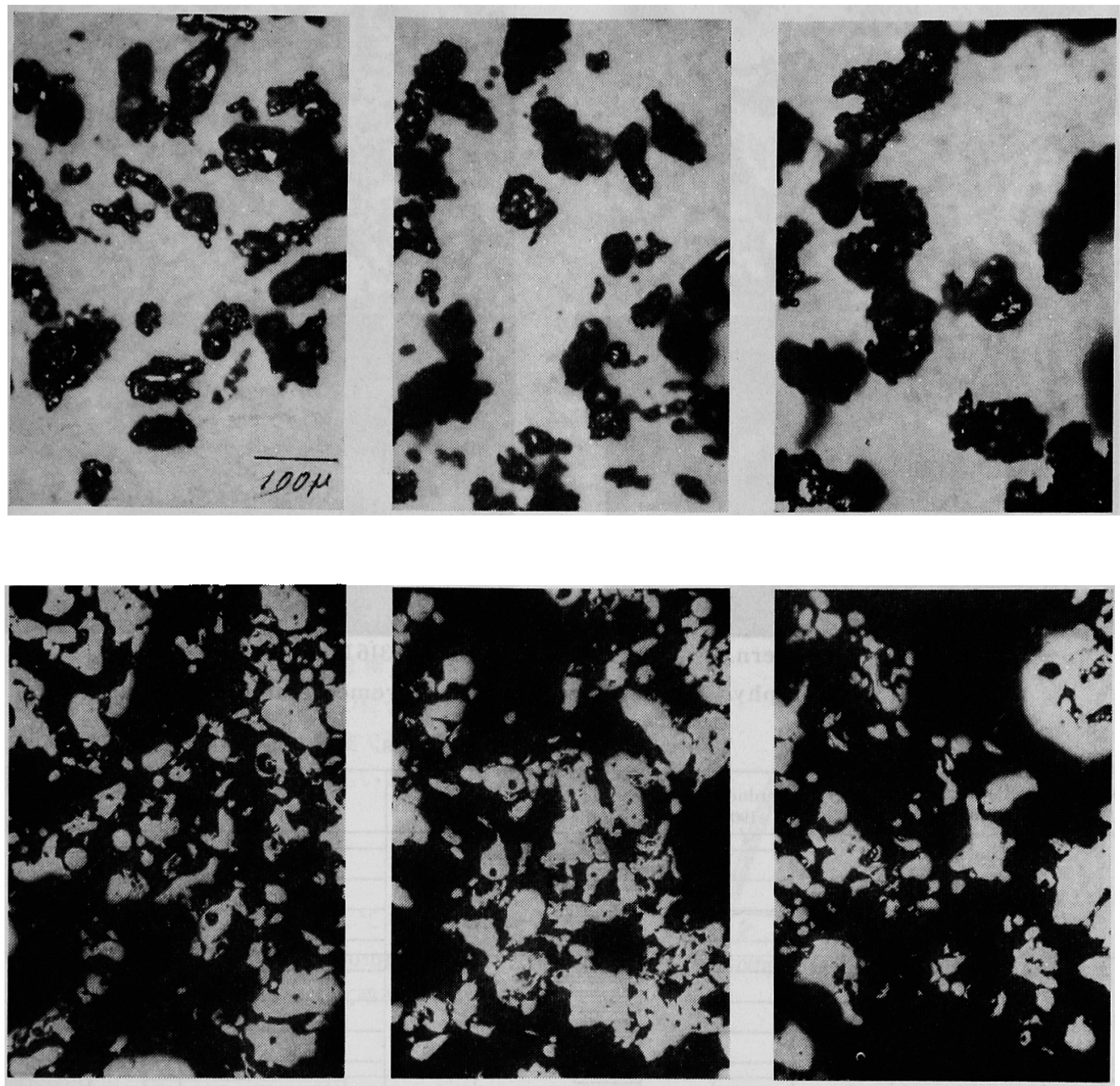

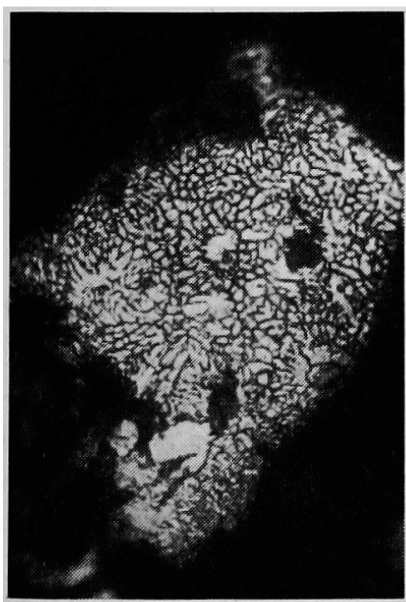

$304 \mathrm{~L}$

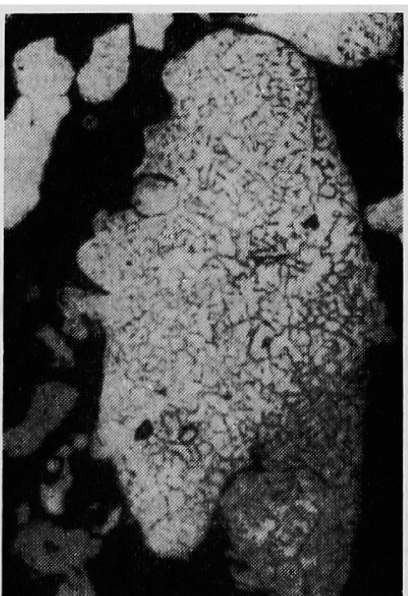

$316 \mathrm{~L}$

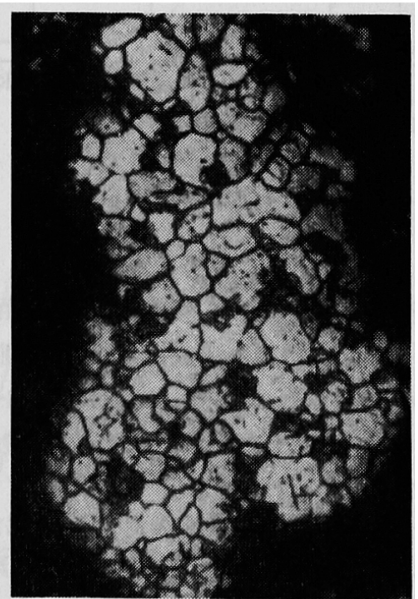

$410 \mathrm{~L}$

Photo. 1. Photograpys of atomized stainless powder. 


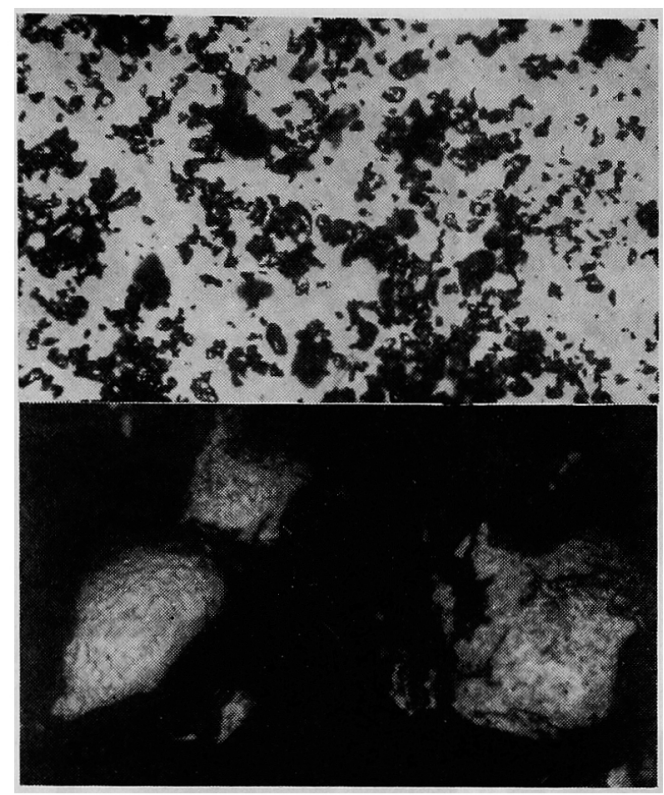

$304 \mathrm{~L}$

(M. Intern.)

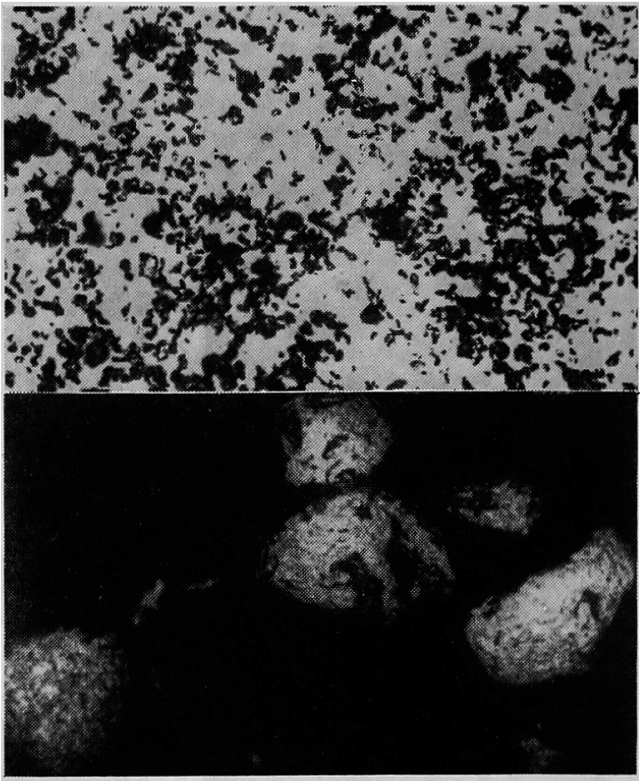

$316 \mathrm{~L}$

(M. Intern. )

Photo. 2. Photographys \& SEM-images of cold-stremed stainless powders.

Table 2. Powder properties.

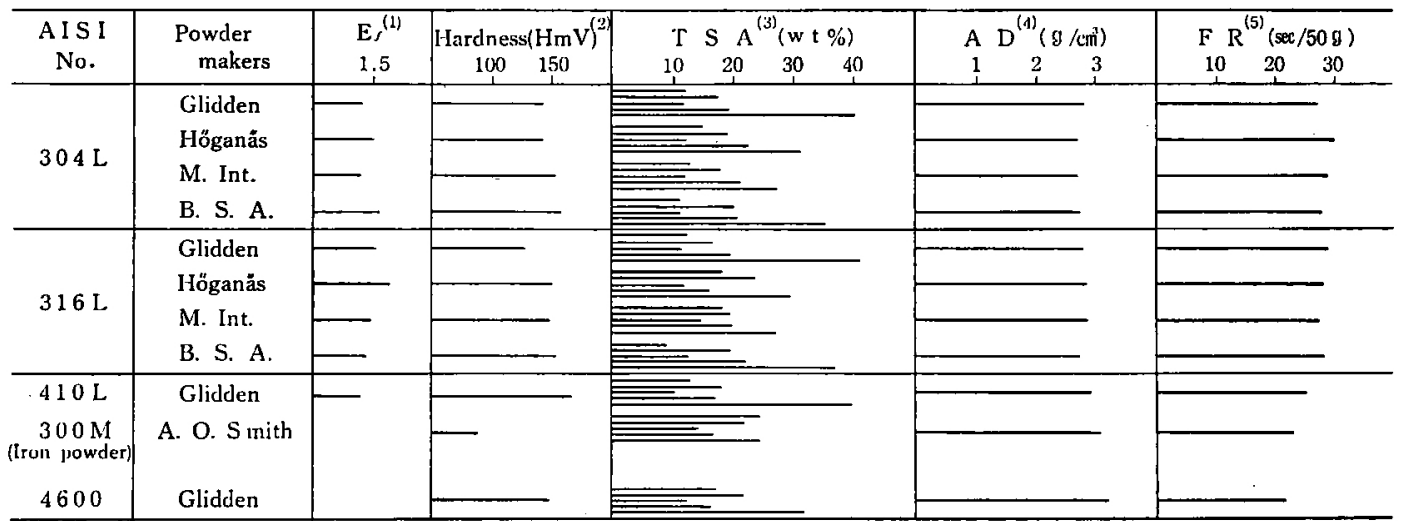

(1) Elongation factor $(=\mathrm{b} / \mathrm{a})$ (2) Load $50 \mathrm{~g}(\mathrm{~N}=10)$

(3) Tyler sieve analysis

$-100 /+150,+200,+250,+325 \&-325$ mesh respectively (in histograms)

(4) Apparent density (5) Flow rate

\section{2 粉体としての性賈}

各粉末の一 100 メッシュにおける粒度分布および見 掛け密度 (AD)，流動度 (FR) の測定結果を Table 2 の台側に並べで示す。C S粉を除けば，どのステン レス鋼粉も同じ製造法によるので，粒形や表面のあら さのスクリーン特性に対する影響10〕に差がないとす れば, Glidden, B S A 両社の粉末はどれもー325 ッシニの微粉側が多く，これから换算した平均粒度は $63 \mu$ 以下であった（Höganäs, M. Intern. および $410 \mathrm{~L}$ は $66 \sim 73 \mu$ )。

これに对し 300M，4600では還元時のアグロマレー トの影響で微粉側が少なくなっているよ5である。ま
た，両ＣＳ粉の平均粒度はカタログ值によれば，304 Lおよび316Lでそれぞれ 15および8.2 2 とされる

(Coulter counter analysis による)。

プレス㭙の圧縮性や能率に関係するパラメータであ る見掛け密度 と流動度は，これら粉末の形状，粒度 （分布）などに左右され，各社の間でばらついている が，オーステナイト系のステンレス鋼粉では，前者が $2.6 \sim 2.9 \mathrm{~g} / \mathrm{cm}^{3}$ 後者が $27 \sim 30 \mathrm{sec} / 50 \mathrm{~g}$ の範囲に入っ ている。これら両特性は原理的に互いに逆数的な值を とるが，流動度についてさらにこれらの見掛け密度と (分析值から求めた) 真密度の比 $\rho_{\mathrm{a}} / \rho$ の逆数に対し てプロットすると Fig. 1 のようなある幅を持った直 


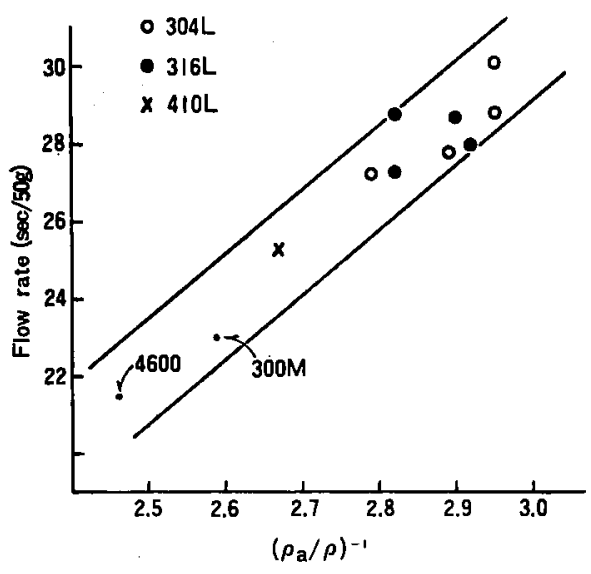

Fig. 1. Relationship between apparent density and flow rate.

線関保が得られる。図中，410Lではいわゆる局部的 なブリッジングが減ったためか，微粉側が多いにもか かわらす流動性るよくなっている。噴霧のままに比 べ，焼なましされたことにより個々の粒子のがどが鈍 化したと考えられる。さらに高、温度で還元され，解

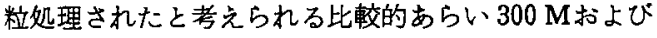
4600では左下方に移動している。

\section{3 プレス圧曾一成形性}

粉末のブリーン（成形）状態に対しての性質は圧縮 性 (Compressibility) と成形性 (Compactibility) の二つに分れる。まず，圧樎性として噴霉ステンレス

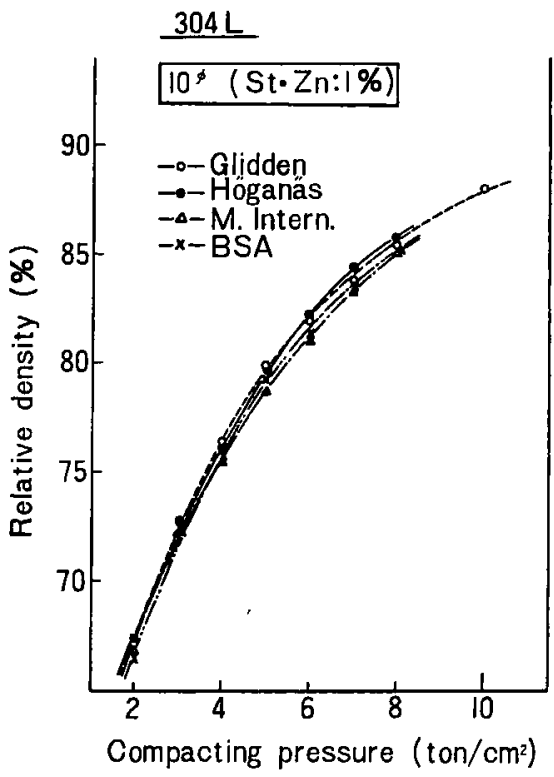

(a)
鋼粉を $10 \mathrm{t} / \mathrm{cm}^{2}$ まで加圧したときのグリーン密度 比との関俰を求めた結果を鋼種ごとに Fig. 2 の(a), (b)および(c)に示す。この場合，各社，各鋼種間での粉 末性状などによる粒間の摩擦やダイ壁面への抵抗の差 を抾大するため直径 $10 \mathrm{~mm}$ の円柱状で寸法比を大きく とり，また高いプレス压での烧きつきを防ぐため閏滑 荗を $1 \%$ と多めにした。

オーステナイト系のステンレス銅粉ではどのプレス

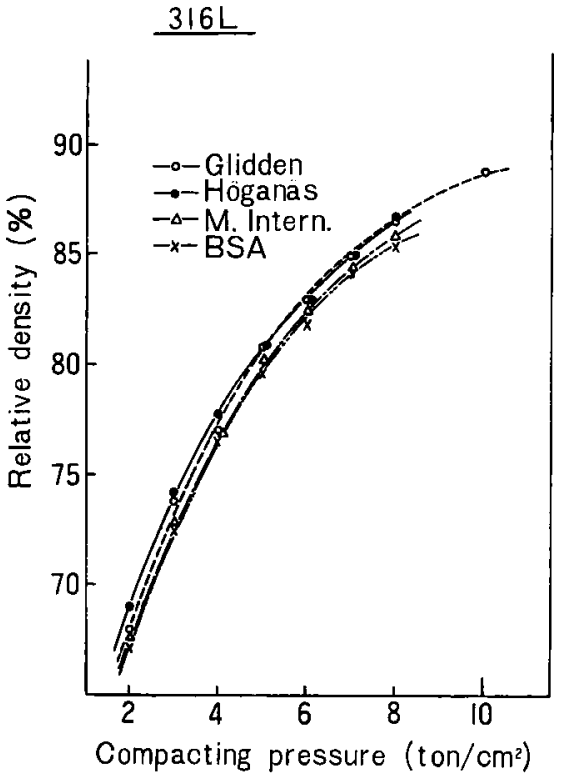

(b)

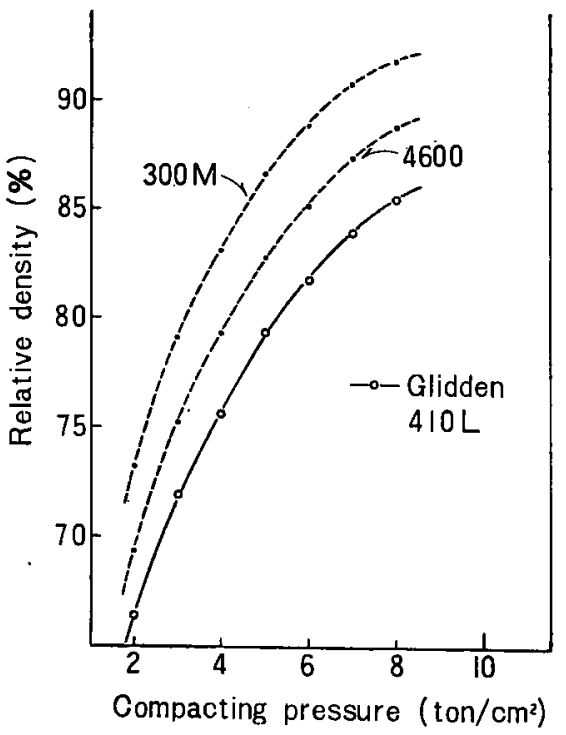

(c)

Fig. 2. Relative green density-pressure curves. 
圧でも Glidden, Höganäs 両社のグリーン密度比レ ベルが相対的に亮く $8 \mathrm{t} / \mathrm{cm}^{2}$ 加生時に $304 \mathrm{~L}$ およ び316L についてそれぞれ 85 打よび 86\%以上となる か: $10 \mathrm{t} / \mathrm{cm}^{2}$ になっても飽和しはじめていない。他 社のも含め, がいして $316 \mathrm{~L}$ の方が $1 \%$ 強圧縮性が よいようであり，分散分析の結果も各社および両鋼種 間に有意差が認められている。(c)の $410 \mathrm{~L}$ を他社と比 較することはできないか，Ni によるひずみ緩和すな く佬なまし後るかためのためやや低いレペルにあり， Glidden 以下 4 社の技術資料カタログなどの諸資料 るあわせてグリーン密度比を推算すると

$$
316 \mathrm{~L}>304 \mathrm{~L}>410 \mathrm{~L} \text { (Ann.) }
$$

といら傾向がある。プレス後の抜出し圧力は $410 \mathrm{~L} の$ 方が数十\%大きい。

このステンレス鋼粉のよ5な固溶型の合金では，一 般に鉄粉などよりプレス㭙の粒子の再配列や塑性変形 （流動）が扰こりにくいことが予想される。事実 300 M, 4600 を含め Fig. 2 の密度比曲線を Balshin 型11) の王縮式にあてはめ，ポロシテイとの関係に書 き換えると相互に活湮平行な直線が得られ，低合金 (配合)の 4600 は $300 \mathrm{M}$ とステンレス鉿両粉の中閒 的なレベルに位置するのがわかる。ただし，ポロシテ 1約10\%以下となると直線からはずれ，材質的なもの からくる加工硬化の影響か現われる。

また，各社のステンレス鋼粉におけるグリーン密度 （比）と見掛け密度（Table 2）とk必ずしも比例的 な関係12) はなく，見掛け密度 $\left(\rho_{\mathrm{a}}\right)$ そのむのは前者 を判断する目安にできない。この $\rho_{\mathrm{a}}$ をバラメータと した Smith の匤縮率18) $\left[\mathrm{C}_{\mathrm{f}}=\frac{\rho_{\mathrm{p}}-\rho_{\mathrm{a}}}{3 \sqrt{\mathrm{P}}}, \rho_{\mathrm{p}}: \mathrm{P}\right.$ で加 圧したときのグリーン密度 から $\mathrm{C}_{\mathrm{f}} \max$ をとり, 真 密度 $\rho$ て除したるのをそれぞれの粉末について比べ ると明らか鋼種に依存している。すなわちこの量 は通常の型プレスに拊けるストロークに対応するもの でオーステナイト采のステンレス鋼粉が比較的大き いのに対し， $410 \mathrm{~L} は 4600$ 之同程度に小さく，後者の 方がプレス操作や能率上からは有利かも知れない。

これら各粉末をプレス压 4 扰よび $7 \mathrm{t} / \mathrm{cm}^{2}$ てで成形 したときのグリーン抗折カとラトラー值について測定 した結果を Fig. 3 と示す。噴䨞ステンレス鋼粉のグ リーン抗折力は，ばらつきが大きく各社間での差はは っきりしないが，ブレス压 4 および $7 \mathrm{t} / \mathrm{cm}^{2}$ でそれ ぞれ0.3〜0.5 および $0.7 \mathrm{~kg} / \mathrm{mm}^{2}$ 以上となっている。
4600は300M より低いが，これはグリーン密叜レベル が低いためであろ5。対応するラトラー值は一部を除 き, $7 \mathrm{t} / \mathrm{cm}^{2}$ で1〜2\%の範囲に入っている。全 般的にGlidden，BSA両社のものが比較的安定した グリーン強さを示している。これら両特性は混入する 閌滑凧の種類や量によっても変化し，またこの場合ダ イへの壁面潤滑にすると粒子間の interlock が増し， 相当圧に括故るグリーン強さは 1.5 倍以上向上するが 実用的な意味は薄い。

試みに互いに粒度（分布）のそろった Gliddenの 3 鋼種について $12 \mathrm{t} / \mathrm{cm}^{2}$ まで加任したときの耐特 性の変化を密度比に対し読取った曲線も，ラトラー值 は相互に交さしてやはりはっきりしなかったが，グリ ーン抗折力の方はどの密度比レベルに哣ても

$$
410 \mathrm{~L}>304 \mathrm{~L} \geq 316 \mathrm{~L}
$$

となり，先のグリーン密度比とは逆の傾向を示した。 とくに，410L は対応するグリーン密度比が低めであ るにもかかわらず，残留ポロシティーが少なくなるほ ぞ他の銅粉との差がひろがり，地の材質的なものが多 少とも作用14)していることが推定される。

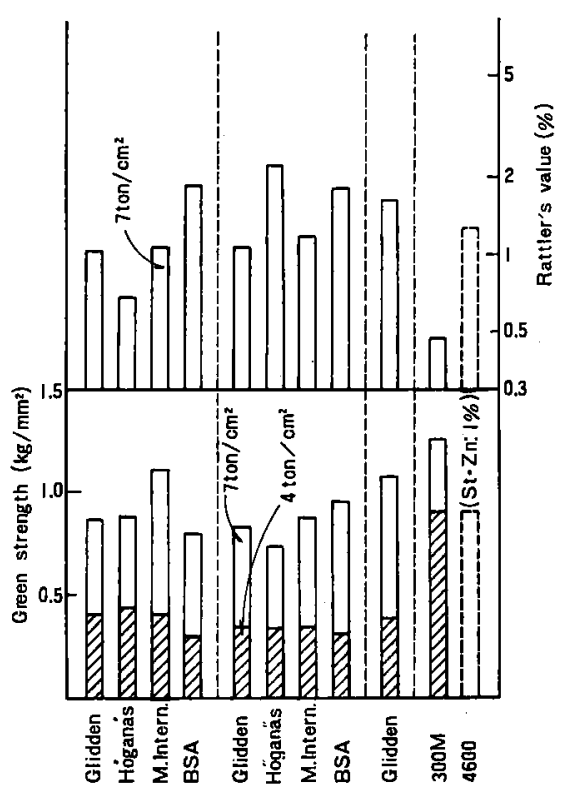

Fig. 3. Powder characteristics.

一般に成形性といってもグリーン強さ(抗折力)に対 しラトラー值がいわゆる耐摩耗性や先端安定性を判断 する值であるといった試験原理上の差があるが，混合 
膶滑の場合の対応する両特性をブロットする（対数）

と Fig. 4 のよ5にある幅を持った直線内に入り，負 の相関関係が見られる。プレス圧 4 および $7 \mathrm{t} / \mathrm{cm}^{2}$ に対する噴璐ステンレス鋼粉はそれぞれ図の左上およ び右下方に集まり，還元処理された $300 \mathrm{M} ， 4600$ はと あに見掛け密度（比）か高いわりに右下方に位置し， 前者に比べて成形性がかなりよいことが知られる。た たし，同じ噴雅ステンレス鋼粉内ではすでに報告15)

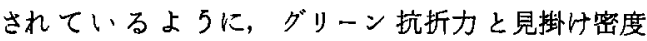

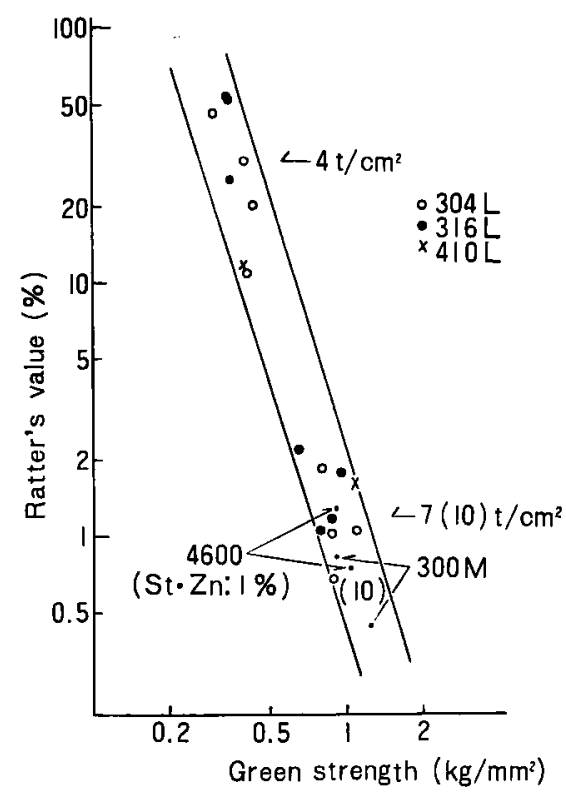

Fig. 4. Relationship between Rattler's value and green strength.

(Table 2) とは一応の相関関保が認められている。

一般に噴務粉は広い粒度分布を持っており，それに 対して粒度オーダの異なる微細粉を適当に混入すると ダイス中での充填構造が有利に変化し18)，見掛け密 度やタッブ密度のほか，圧縮一焼結性も促進すること が期待できる。そこで数十 $\mu$ 以下の両 C S 粉をそれぞ

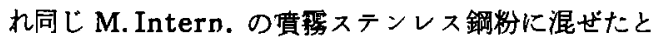
き（プレス成形条件は Fig. 2 と同じ）の見掛け密度 およびおのおののブレス压一密度比曲線を求め，それ から䛨取った 4 および $7 \mathrm{t} / \mathrm{cm}^{2}$ 加圧時のグリーン密 度比の変化を対応する見掛け密度とともにブロットす ると Fig. 5 のごとくなった。埌からこの混合系の見 卦け密度は両鎆種とも約 $40 \%$ で最大值をとり，この混 合比あたりでグリーン密度（比）す上昇することが予 想される。しかし，この場合のグリーン密度比はC S 粉を混入するにつれ漸減するので本来の性状をそこな

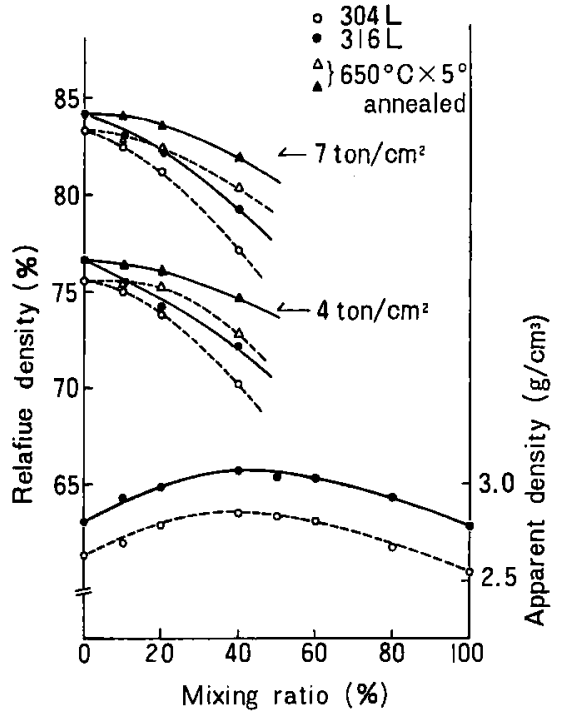

Fig. 5. Characteristics of binary particle mixture. (atomized and CS-powder's)

わない低温側（長時間）で㜞化焼なましを施したもの についてむ試みたが，単に密度比レベルが上昇する （図中 $\Delta$ 印）にすぎない。これは走查電子顕微鏡の観 察結果が示すよ5にCS粉は5ろこ状であり，プレス 時の個々の粒子が粒間をすべる粒子扗散能や压力伝達 などの縮密化過程が変化してくることによるものと考 えられる。またこのC S 粉の混入につれ成形性はか なり低下し，たとえば 100\%のときにはプレス圧を10 $\mathrm{t} / \mathrm{cm}^{2}$ 程度かけてもラトラー值は $10 \%$ 以上もあっ た。

\section{4 焼 結 性}

プレアロイしたステンレス鋼粉の常用の焼結温度は 一般に鉄粉より高めの $1,150 \sim 1,200^{\circ} \mathrm{C}$ とされている。 この中間的な温度の $1,180^{\circ} \mathrm{C}(\times 40 \mathrm{~min})$ で Fig. 2 に対応した圧粉体を真空烧結したときの密度比を軸方 向の寸法変化率とともに Fig. 6 の(a)，(b)および(c)に 示す。先のグリーン密度比を反映し，どのプレス圧で も Glidden, Höganäs 両社の焼結密度比レベルが 相対的に高いか，後者の贲結時の寸法変化率はいずれ あ小さいので密度のあがり方は少ない。これは両鋼種 とあ前者の方が微細であるため，それより誘起される 収縮の差17によるものであろら。オーステナイト系 のステンレス鋼粉の密度比は両鋼種ともほほ同じとな り，たとえば 6 および $8 \mathrm{t} / \mathrm{cm}^{2}$ 加圧したるのはそれ ぞれ 84〜86および 88\%以上を得ている。るとの粉末 をとくに走查電子顕微鏡により低倍率で観察したとこ ろ, Glidden 粉では理想的に不規則形状の中に微細 
な球状粉が多く散在しておらりこのため寸法変化率が $2 \%$ 以上ななり，さらに低温です焼結性のよいことが 推定される。

これらの分散分析の結果も鋼種よりす各社間の方が 有意差を示した。これに对し $410 \mathrm{~L}$ はグリーン密度 （比）が低めであっても焼結時の収縮が大きく、プレ ス压 $7 \mathrm{t} / \mathrm{cm}^{2}$ ですでに密度比 $90 \%$ を越し, 焼絬温度 そのものが異なるため直接比較はできないが，鉄粉の それに近い（焼結密度自体 は相当する $316 \mathrm{~L}$ とほほ 同じ $7.0 \mathrm{~g} / \mathrm{cm}^{3}$ 胎)。試みに, ら密化係数を概算する とオーステナイト系の あのより 2 倍近くあり $\alpha-\gamma$ 雨相の焼結時の拡散メカニズム18）の差によるところ が大きいものと解积される。

この関係はも5一つのブロセス条件であるつぎの焼 結温度 (時間)による変化の試験により明らかとなっ た。互いに粒度(分布)のそろった Glidden の3 鋼種 を例にとり焼結温度を $1,350^{\circ} \mathrm{C}$ まであげたとき，軸方 向の寸法変化率および得られた烧結体の密度比の変化

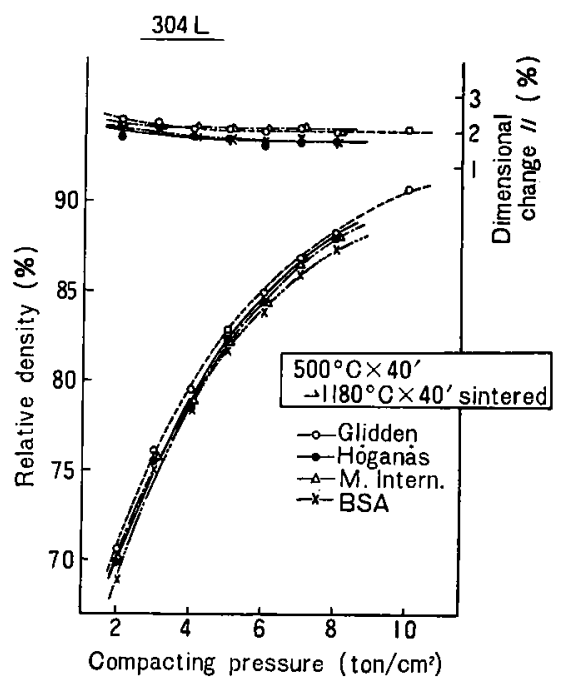

(a)

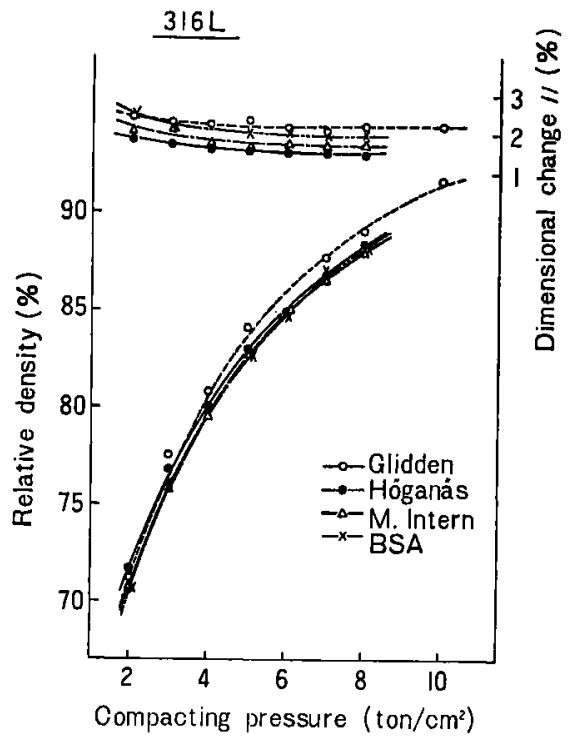

(b)

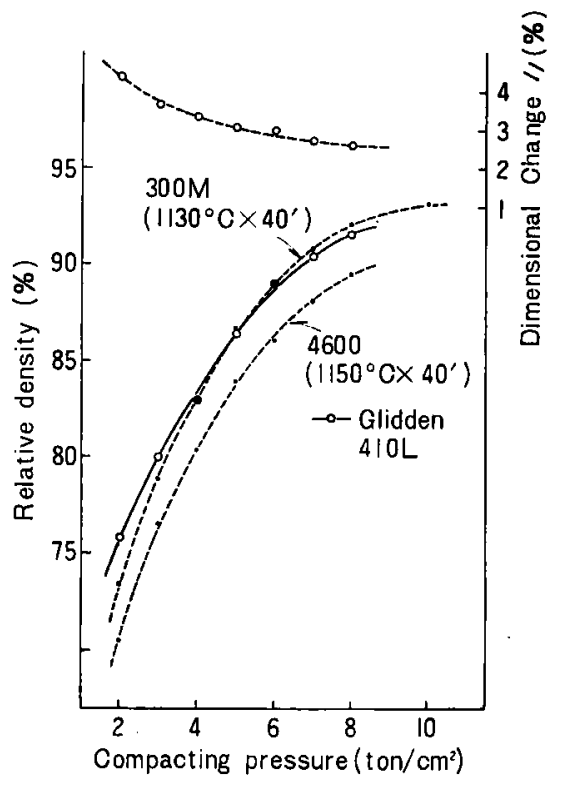

(c)

Fig. 6. Relative sintered density-pressure curves.

を求めた結果を Fig. 7 に示す。この場合は目的上A STMの標準的なダイス（試料の寸法比約 1：1）に よったため, Fig. 6 の密度比レベルよりやや高めで ある。図から焼結温度があがるにつれ密度比は 1,100 ${ }^{\circ} \mathrm{C}$ あたりより立上がり，その後は $304 \mathrm{~L} ， 316 \mathrm{~L}$ とも 平行で医匡線的な増加を続けるが，これは低 $\mathrm{Si}$ (<1\%)のオーステナイト系ステレンス鋼粉特有15) の現象とされる。 $1,350^{\circ} \mathrm{C}$ の高温での焼結ではいずれ
も $92 \%$ 程度になる。これに対し $410 \mathrm{~L} は 1,000^{\circ} \mathrm{C} て ゙$ 見 掛け上やや膨脹（図中の矢印）したのち $1,200^{\circ} \mathrm{C}$ まで 焼結温度の上昇とともに急激にち密化しているか，こ れはこの種のフェライト系における焼結速度（定数 Ko）がかなり大き(10)ためである。しかし，それ以 上の温度では結晶粒の粗大化が著しく（写真による観 察)，収縮はやや低調となる。すなわち，粒界密度が 小さくなって粒界にそった空孔の移動とその表面から 


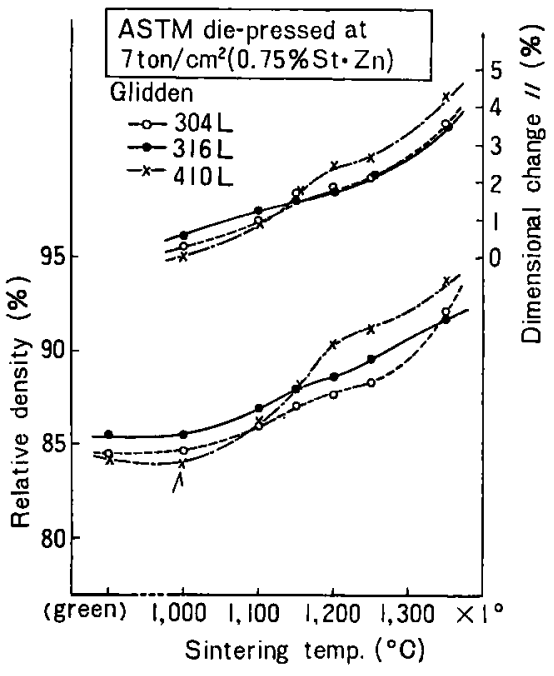

Fig. 7. Effect of sintering temperature on sintered density.

の消滅が押えられ201たためと解釈される。 一方，デラトメータによりこれら膨脹一収縮の連続 的な観察 $\left(100^{\circ} \mathrm{C} / 10 \mathrm{~min}\right.$ で昇盜を行なったところ) では $304 \mathrm{~L} ， 316 \mathrm{~L}$ および410 L はそれぞれ 910，860 および $820^{\circ} \mathrm{C}$ あたりで収縮しはじぬる。噴霧時の残存: $\delta$ 相を数\%含む $316 \mathrm{~L}$ ではそれより低めの温度でチャ ート上にフェライト分解の屈曲が現われるが，いずれ にしても $\alpha$ 相リッキのものでは焼結開始点は低温側に 移るものと推定される。

以上のことから,オーステナイト系のステンレス龬 粉はち密化が遅く，高密度化与るにはプレス压を高く とるよりも，高温で烧結する方が有利なことが知られ る。しかし，真空焼結に限らずふん囲気がスによる烧 結の湯合も含めて, 経済的には, $1,250^{\circ} \mathrm{C}$ 以下に押え るよ5に焼結材の製造プロセスを組合わせざるを得な いであろら。

この温度に対する焼結進行度は機械的な粒子間の接 合の強さによっても判断される。その一つの方法とし て, Fig. 7 に対応し，簡便な小試片による曲げ試験 を行なった結果（Fig. 7 と同じくブレス圧 $7 \mathrm{t} / \mathrm{cm}^{2}$ で成形）を焼結材の結晶粒度およびかたさとともに Fig. 8 k示す。試片は短いためせん断力が入り，ま たポロシティーの差21 があるために絶対值自体を論 議することはできないが，最大曲げ応力 $\sigma_{\text {max }}$ はいず れの鋼種も $900^{\circ} \mathrm{C}$ で立上がり， $1,150^{\circ} \mathrm{C}$ あたりまでほ 漂線的に増加し，その点でオーステナイト系では一 種の降伏状態に移っている。この $\sigma_{\text {max }}$ の立上がりは Fig. 7 に比べ低温側にずれているか，先のデラトィ ータによる湘定結果ともあわせて考光ると，すでにこ

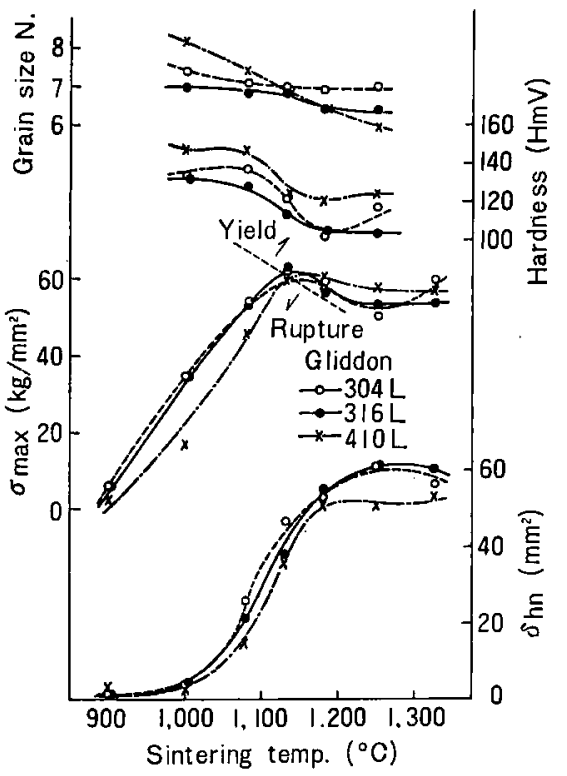

Fig. 8. Effect of sintering temperature on bend strength of sinterd materials.

の $900^{\circ} \mathrm{C}$ で焼結初期の段階における接触粒子間のネッ クの発生と物質移動22) がかなり起っていることが推 定される（ブリケット状態での強さはたかたか 1 $\mathrm{kg} / \mathrm{mm}^{2}$ )。この動きに対しじん性を表わす $\delta \mathrm{hn}$ (ひず

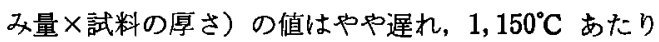
から急激に向上するが，これは焼結体内のポフーの球 状化しはじめる時期と一致することを確認した。この 点でミク口的なかたさる低下するが，その後は才ース テナイト系で $\mathrm{HmV} \mathrm{100,410L} \mathrm{で} 120$ 程度に安定し ている。後者は先の高密度化の傾向とあわせて考える とマクロかたさ的な性質はかなり大きいはずで，焼結 のままで耐食性とともに耐摩耗性を要求されるよ5な 用途に適するものと思われる。

つきに，Fig. 6 と同じ条件で真空烧結したC S粉 との混合粉についてプレス圧一焼結密度比曲線を求め た結果の例 (304L，軟化焼なむし後）を Fig. 9 に 示す。焼なまし以前のかたいC S 粉を湿入したときは グリーン密度比のレペルそのものが低いため（残留ひ ずみのため28，焼結時のち密化は後の烧なまし粉より 大きいが） どのプレス圧の焼結体も母粉上なってい る該当噴雾ステンレス鋼粉だけの密度比以上になるこ とはなかった。しかし， $650^{\circ} \mathrm{C}$ の軟化焼なまし後のC S粉に対しては Fig. 9 に見るよ5に，CS粉の混合 比10または $20 \% の$ 方か $1.5 \%$ 以内の範囲で密度比が高 くなる。そして $40 \%$ なで混入すると烸結時の寸法変化 率はかなり大をくなるが，焼結体の密度比レベルその すのはやはり低下するよ5である。この種の微粉の混 


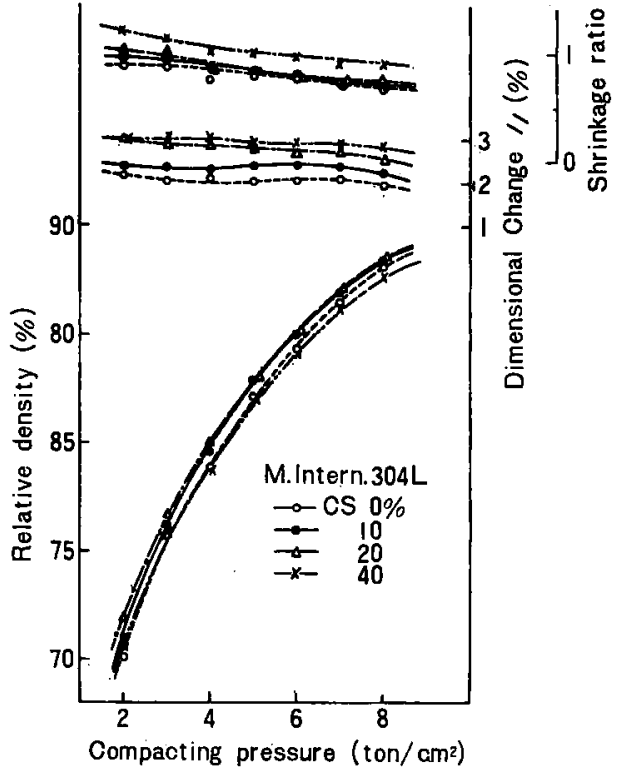

Fig. 9. Relative sintered density-pressure curves of binary particle mixture system.

入によるち密化の現象は，不規則形状をした噴筬粉の すきまに入り，そのすきまを充てんすることによって 粒子閒の接触を増し17)，瑨結性を促進した結果であ る。これは Fig. 9 で加圧力を大きくし，粒子の塑性 変形により全体的な接触点を多くしたもの注ど密度比 の上昇は相対的に少なくなり，また湜合比を多くする 汪ど母粉に対する収縮比（径方向/軸方向の寸法変化 率の比 ${ }^{24 \prime} ）$ レベルが上昇していることです裹づけら れよ5。この楊合は形状や粒度などの点で，微細な球 状粉による報告25) よりも低い混合比のところに最大 値があり，効果も少ない。M. Intern. の報告日)で い5よ5kCS粉を “full density parts” の手段 として利用するには，まだ疑問があり加エブロセス的 な研究の余地力残されている。このC S 粉の混った燃 結体のポアー・モホロジーは比較的細かく均一に分散 した状態を呈し，前記のち密化の傾向とあわせて考察 すると焼結材の強度への刘果26) はかなり期待される ものと考えられる。

\section{5 焼結体の性䝿}

焼結以後の性質は各社の粉末間の品質的な差は少な くなることが予想されるので，ここでは一般のステン レス鎆材に準じ，機械的性質と耐食性について簡単に 調べることとした。

まず，機械的性啠としてはプレス压を一定（7 $\mathrm{t} / \mathrm{cm}^{2}$ : ステフリン酸亚鉛 $0.75 \%$ とし，Fig. 7 拧 よび 8 の結果から見て諸特性が比較的安定する 1,180 ${ }^{\circ} \mathrm{C}(\times 2 \mathrm{hr})$ で真空烧結した材料の弓張り試驗とシャ
ルビー試験（ノッチなし）の二つを実施した。その結 果をそれぞれ Fig. 10 および11に示す。

Fig. 10 から噴琵 ステンレス鋼粉の引張り強さ，お よび耐力は各社間での差ははっきりしないがオース テナイト系ではそれぞれ 25〜28扰よび 15〜 18kg/ $/ \mathrm{mm}^{2}$ の範囲に入り，伸びは $8 〜 12 \%$ を得ている（300 M と 同程度）後の伸びには各社での系統的な差がかなり 認められ，両鋼種ともGlidden より Höganäs, $M$. Intern. 両社の方がやや上い。一般に焼結材の相対 的な強度はポロシティの罢乗に依存 25 ) するとされる

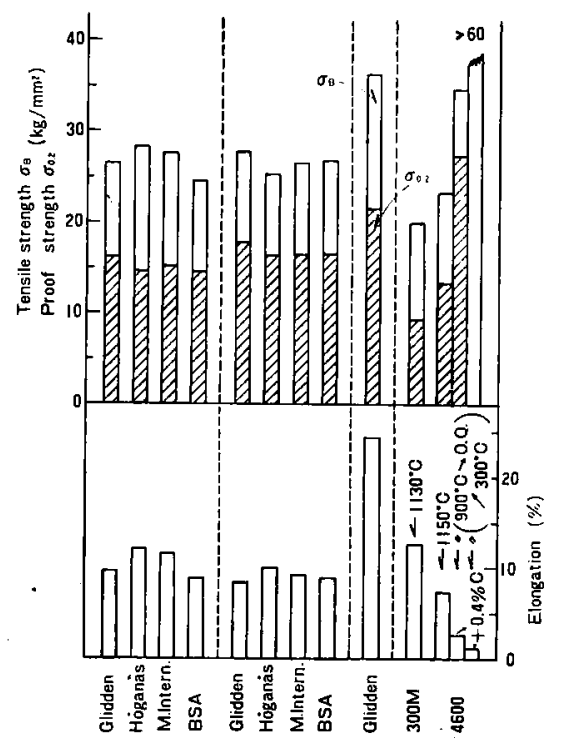

Fig. 10. Results of mechanical test of sintered materials. (I)

かi, Glidden の 316L を除き Fig. 6 の焼結密度比 に必すしも対応していない。これは試料の調整を含む 試験的な誤差が大きいことも一因であろ5。これに対 し $410 \mathrm{~L}$ の引張り強さおよび耐力はそれぞれ36および $22 \mathrm{~kg} / \mathrm{mm}^{2}$ に達し，その右の 4650 亿打ける $0.4 \% \mathrm{C}$ 添 尽焼結材（燒結のまま）に匹敵する。伸びも25\%近く を得ており，材質的なもの以外に高密度化の影響も奻 果を及剠ているすのと考えられる。

衝撃値はB S Aの 304L を除きオーステナイト系で $8 \sim 10 \mathrm{~kg} \cdot \mathrm{m} / \mathrm{cm}^{2}$ となり, やはり各社間, 鋼種間で の差ははっきりしない。また，この衝慗值を Fig. 10 の伸びと比べ（ポロシティ依存度は異なるが）ても必 ずしす対応していない。かたさの方は $\mathrm{H}_{\mathrm{R}} \mathrm{F}$ 約70で任 ぼ一定しているといえる。一方，410L は $12.5 \mathrm{~kg}$. $\mathrm{m} / \mathrm{cm}^{2}$ となりじん性に富んでいる。比較的かたく先 の引張り試験の結果とあわせると，他のステンレス焼 結材に比べ溶製材の規格レベルに最も近いとい克る。 


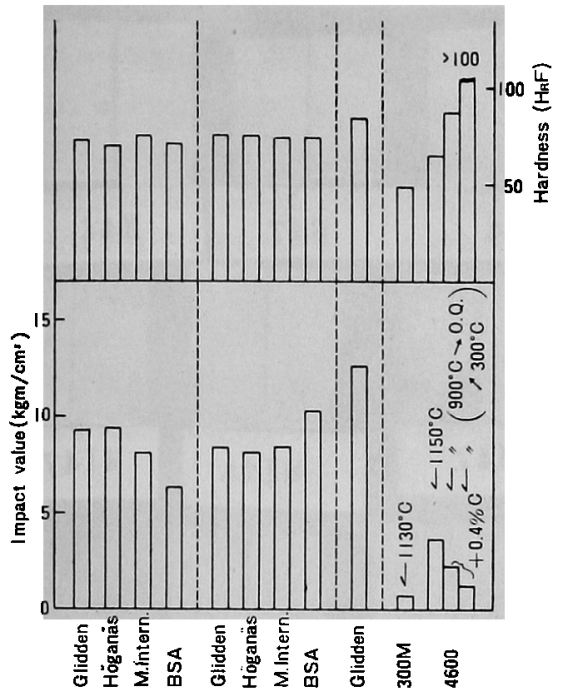

Fig. 11. Results of mechanical test of sintered materials. (II)
これらの試片の破断面の走查電子顕微鏡による観察例 を対応するミク口組織（いわ少るれ食を避けるため弱 くエッチ)とともに Photo. 3 に示す。この写真から 410L の方がポーか球状化し，また破断面の様子か らかなりじん性破壊しているのが推定される。

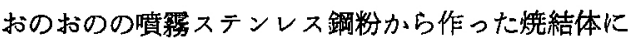
ついて $48 \mathrm{hr}$ 塩水噴霛試驗（ $5 \% \mathrm{NaCl}$ 溶液）した結 果をまとめて Photo. 4 亿示す。ただし，脱ろ5（分 解）後のステアリン酸业鉛の残存によるCビック・ア ップを避けるため，混入量は $0.5 \%$ と少なめにしてあ る。(a)はGlidden の 3 鋼種についての差を見たもの で、オーステナイト系に比べ $410 \mathrm{~L}$ は明らかに発錆度 が大きい。つぎに，この耐食性のよい304L（316L む 同じ）に対し各社間での発鑜度を相互に比較した(b)で 両鋼種とも系統的な差はほとんどない。一部の試料で 端部に発錆しているものがあるが，これは試験中の水 溶液の帯留によるものである。これら各社の両鎆種に
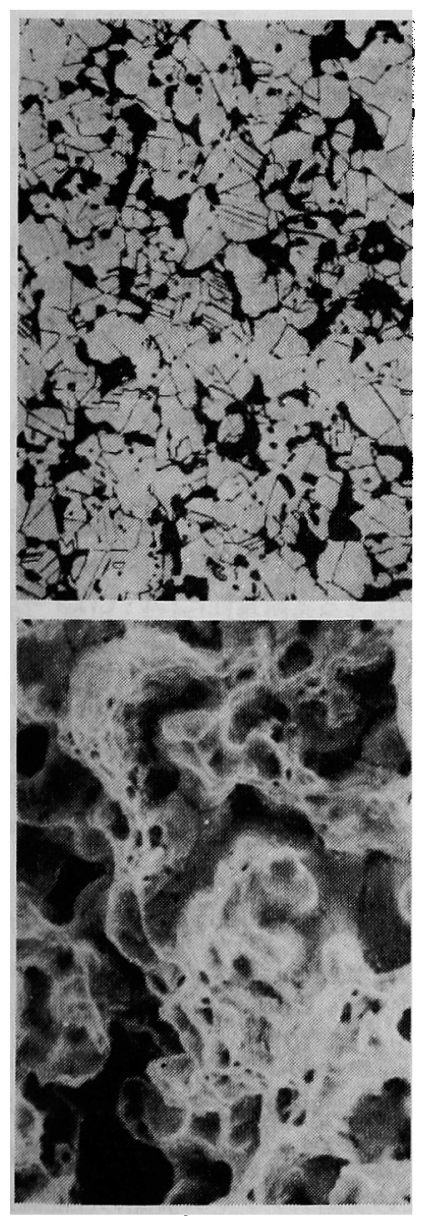

$304 \mathrm{~L}$
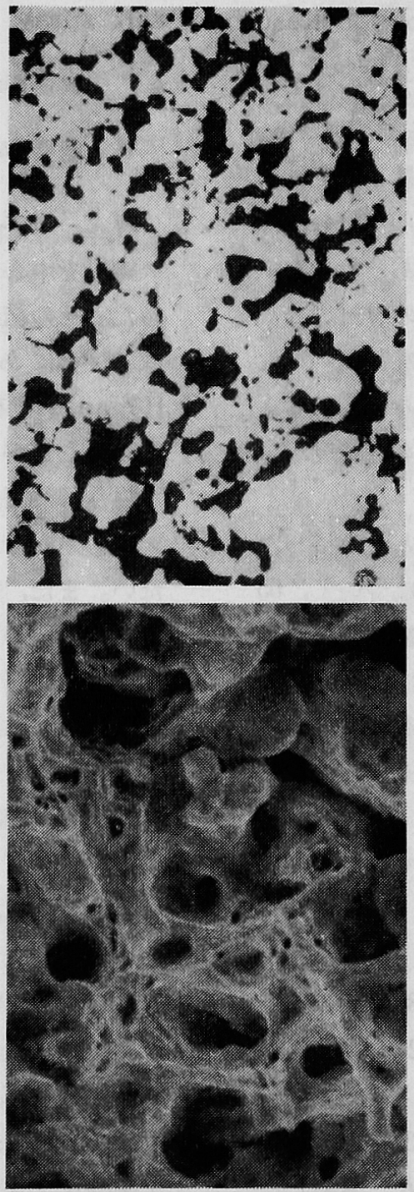

$316 \mathrm{~L}$

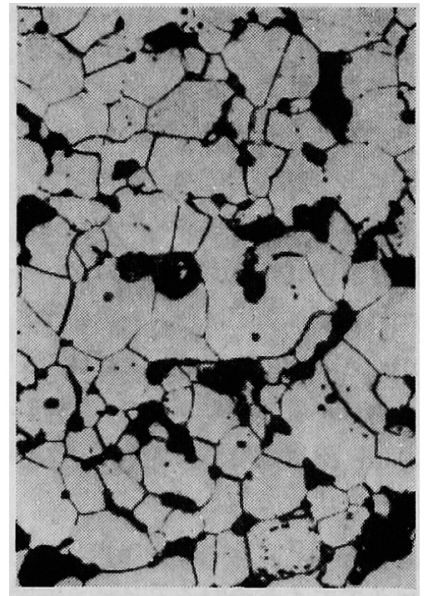

$\times 200$

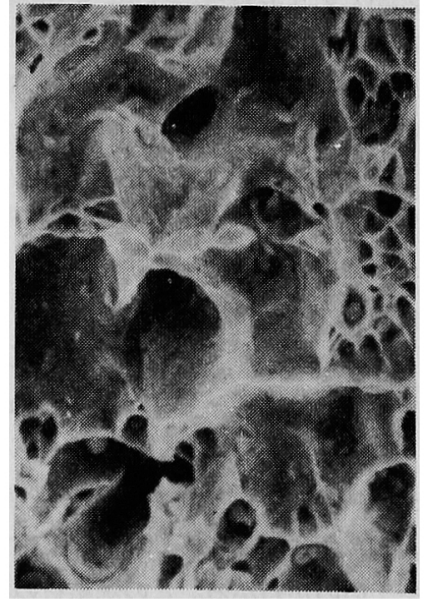

$410 \mathrm{~L}$

Photo. 3. Fracture surfaces of sintered materials. 


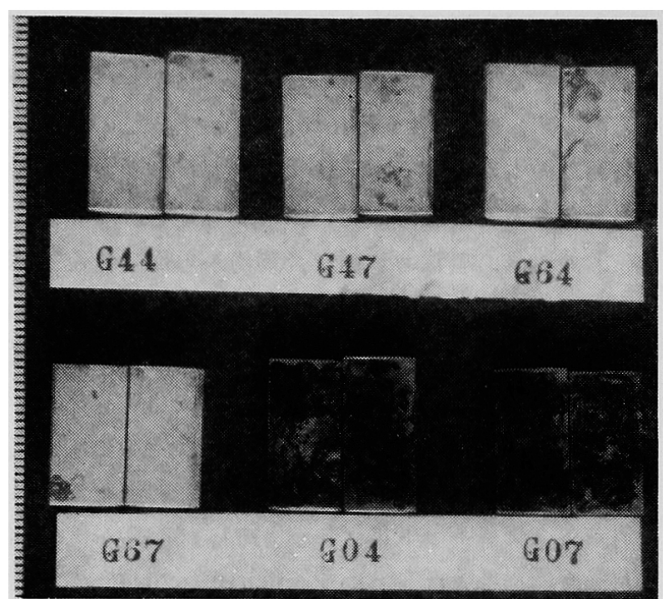

(a)

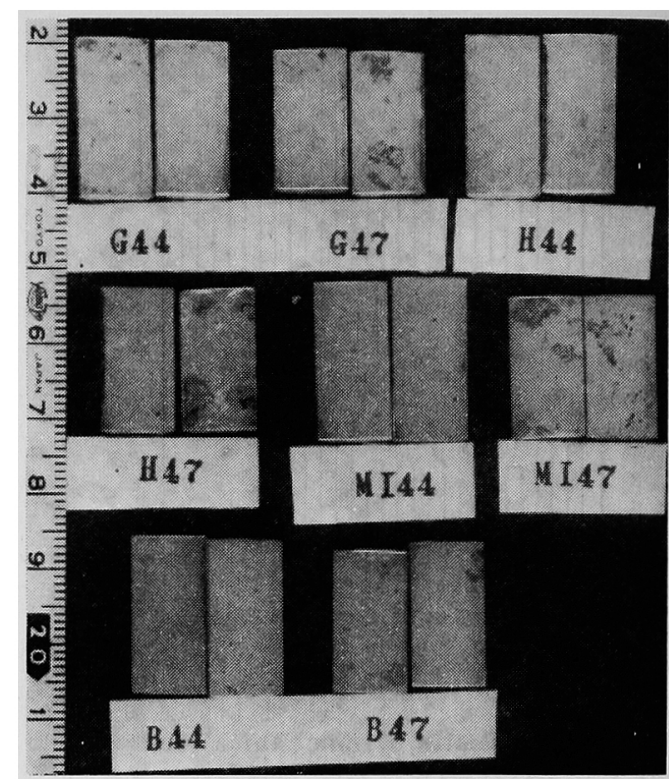

(b)

Photo. 4. Results of salt spray test.

対して焼結体表面のオープン（開口）ポアーの量を相 対的に変化させることをねらい，プレス压をより広い 範囲にとり試験を行なった結果でも空孔量とのやはり はっきりした相関は認められない。これら試片の組織 に括ける炭化物判定の結果は2〜3 級であった。本試 験では焼結体表面は軽くバフ研摩したものを対象とし たが，この種の店食は仕上げはだや上記残留ポロシテ イーの潘か焼結時のガスふん囲気にすよることが考党 られる。真空焼結したステンレス鋼が最も発錆度が少 ない28)よ5である。

つぎに，プレス圧を $7 \sim 9 \mathrm{t} / \mathrm{cm}^{2}$ にとり成形した オーステナイト系のステンレス鋼焼結体について，65 \%沸腃硝酸および $5 \%$ 沸勝硫酸に対する腐食减量試験 を行なった。この両腐食とも焼結体表面におけるすき まにそって進行するので, 前記オープンポフーの状態 や量（比表面積）に対し敏感であると考光られる。そ こで得られた結果を密度比で整理し直し，例えばポロ シティ12\%の点を内そうすることによっておのおのの 腐食減量を求めたが,

[304L] [316L]

\section{$65 \%$ 沸腃硝酸 $\quad 40 \mathrm{~g} / \mathrm{mH} \quad 80 \mathrm{~g} / \mathrm{mH}$ $5 \%$ 沸腾硫酸 $>400$ " 220 "} のオーダでばらつき，各社間での差は見られなかっ た。鍋種的には前者が $304 \mathrm{~L}$, 後者では $316 \mathrm{~L}$ の方が ややよいのがわかる。この焼結材の場合も，溶製した ステンレス鋼材と同様に $5 \%$ 沸滕硫酸，すなわち非酸 化性環境にむしろ弱いが，この程度の密度比における
絶对值自体は約 2 けた近く低いよ 5 である。

\section{4. 総括および結言}

以上, 粉末や金用の輸入市販の 4 社の噴霧ステンレ ス鋼粉を中心に特性試験を行ない，相互に品質比較を した。その結果粉末の性状やプレス一焼結性に対して は各社間にあまり差はないが，総じて Glidden, Höganäs 両社のステンレス鋼粉はよく, 使いやすい といらことができると思う。

得られた焼結材の性質については，その調整ブロセ スにも左右され本試験結果からたけでは優劣はつけが たい。また，鋼種的に見ると耐食性についてはオース テナイト系のものより $410 \mathrm{~L}$ の方か明らかに劣るが， 一方焼結性がよく密化しやすいために焼結材の機械 的性質などはかなりよく，ステンレス鋼粉として一般 的なブレス一焼結程度の密度比でもじん性などは溶製 材の性能(大略，伸び $\geq 25 \%$ ，衝撃值 $\geq 10 \mathrm{~kg} \cdot \mathrm{m} / \mathrm{cm}^{2}$ ) に近くなっている。

しかし，本試験においては焼結を真空中で実施した ため焼結時に比較的高密度化しやすく，じん性などの 諸性質も相対的によくなっていると考えられる29)が， 実用上は用途に応じ，経済的な焼結温度で，またアン モニア分解がスなどのふん囲気がスを使って燃結する 場合が多いと思われる。さらにこれらの問題を含む 工業的なプロセスでの笎結ステンレス製品の性能調查 む必要であろ5。しかし，これにより医原ブレアロイ したステンレス鋓粉について最大公約数的な技術判断 
資料を得ることができた。

現在国内で実際に輸入市販されている㸮末や金用の （水噴霧）ステンレス鋼粉は，通常の溶製材に㧊ける $304 \mathrm{~L} ， 316 \mathrm{~L}$ 扰よび $410 \mathrm{~L}$ などに相当するものたけけで あり，特性的にも限られてくる。今後溶製材に匹敵 し，またはそれでは得られないよらな粉末や金独特の 性能を付与した新しいステンレス鋼粉の開発が期待さ れる。

終わりに耐食試験関係て協力された大同製鋼碀研究 開発本部中央研究所の河野富夫氏に感謝の意を表す る。

\section{（文献）}

1) A. Adler : Iron \& Steel Engr., 48 (1971), 69

2) H. H. Hausner : Plansee. Pulvermet., 14 (1966), 75

3) C. G. Goetzel : Treatise on Powder Met., 2 (1950), 777

4) A. H. Grobe, G. A. Roberts : J. Metals Trans., 3 (1951), 125

5）昭和 49 年度日本金属学会春期大会（東京）にて 発表

6) C. B. Brandstedt : Precision Metal Mold., 27 (1969), 52

7) I. A. White : Proc. Conf. Met. Soc., 23 (1966), 9

8）田村, 武田：粉体および汾末冶金, 12 (1965), 25

9）田村，觡川：粉体および粉末治金，15（1968）, 302

10）荒川：材料, 19 (1970)，612

11) R. W. Heckel : Trans. AIME, 221 (1961), 1001

12) A. R. Poster : Handbook of Powder Met., (1966), 17
13) G. B. Smith : Metal Ind., 72 (1948), 427

14) A. Stosury, R. R. Holems : Metal Prog., 91 (1967), 81

15) R. L. Sand, J. F. Watkinson : Powder Met., (1960) 5/6, 105

16) D. R. Hudson : J. Appl. Phys., 20 (1949), 154

17) J. S. Hirschhorn, G. M. Maxwell, A. V. Nadkarin : Powder Technol, 5 (1971), 147

18) C. J. Meechan : Phys. Rev. Letters, 4 (1960), 284

19）武田，田村：粉体求よび粉末治金，17（1971）, 220

20) J. E. Burke : J. Amer. Ceram. Soc., 40 (1957), 80

21) I. M. Starozhevskii, P. G. Arabadzhi et al. : Soviet Powder Met. Metal Ceram., (English Transtl.) 11 (1969), 927

22) F. Thümmler, W. Thomma : Metals \& Materials 1 (1967), 69

23) C. C. Fatino, J. S. Hirschhorn : Trans. AIME, 239 (1967), 1499

24) O. V. Romman, H. H. Hausner : 粉体扰よ び粉末冶金, 9 (1962), 228

25) H. H. Hausner : J. Metals, 13 (1961), 752

26) V. Gallina, G. Mannove : Powder Met., 11 (1968), 73

27) M. Eudier : Plansee. Pulvermet., 14 (1966), 29

28) R. L. Sand, C. F. Bidmead, D. A. Oliver : Modern Dev. in Powder Met., 2 (1965), 73

29) R. L. Sand, J. F. Watkinson : Powder Met., (1960) 5/6, 65 